\section{Admission of old people to hospital}

SIR,-The experience of Dr A A Baker (4 September, $p$ 571) and your subsequent correspondence highlight the problems that the elderly face when they have a diminishing role.

Dr Muir Gray (23 October, p 1007) refers to my own research ${ }^{1}$ and this does show how a group of very old, very disabled people can be kept at home. Certainly they had small, purpose-built homes and slightly above average support from social services, but they also had very strong links with relatives to whom they gave help as well as receiving it.

The City University,

ANTHEA TinkeR

Tinker, A, Housing the Elderly: How Successful are Granny Annexes ?, HDD Occupational Paper 1/76.

London, Department of the Environment, 1976.

\section{Amniotic fluid alpha-fetoprotein and congenital hydrocephalus}

SIR,-In your leading article "Epidemiology of anencephalus, spina bifida, and congenital hydrocephalus" (13 November, p 1156) you state that "estimation of alpha-fetoprotein in early pregnancy has given such impetus to controlling anencephalus, spina bifida, and congenital hydrocephalus. . . ."

There is no doubt that a raised level of amniotic fluid alpha-fetoprotein (AFP) is found in anencephalus and open spina bifida whether or not the latter is associated with hydrocephalus. Isolated congenital hydrocephalus is not associated with a raised amniotic fluid AFP concentration and therefore cannot be diagnosed prenatally by this investigation. This is illustrated by the following case report.

A mentally retarded unmarried girl aged 22 years was seen early in pregnancy. She herself had isolated congenital hydrocephalus. Amniocentesis was performed at 16 weeks and a normal AFP level found in the liquor. Pregnancy continued and at term she was delivered of a stillborn hydrocephalic male infant after perforation of the skull. Post-mortem showed hydrocephalus (head circumference $38 \mathrm{~cm}$ ) with dilatation of the ventricular system and thinning of the cortex to $0.8 \mathrm{~cm}$. There were no other abnormalities.

\section{ELSPETH M WILLIAMSON \\ D C SIGGERS \\ J F MILLER}

Departments of Child Health and Human Reproduction,

Southampton General Hospital,

\section{Vitamin $A$ and lung cancer}

SIR,-Dr A Sakula (31 July, p 298) points out that in a study of patients with lung disease serum vitamin A levels were found to be lower in patients with bronchial carcinoma than in those with benign lung disease or healthy age-matched control subjects. ${ }^{1}$ These findings are consistent with previous clinical and experimental work suggesting a correlation between low serum vitamin A levels and tumour progression. ${ }^{2}$ They may also provide a reasonable explanation for the antitumour effect of vitamin A or its analogues. Though extensively investigated in a number of laboratories during the last decade, it is not yet established whether this effect is due to the presence of an excess of vitamin A, an increased need for vitamin $A$ in the presence of a carcinogen, or even an increased susceptibility to carcinogens following inadequate vitamin A consumption. ${ }^{3-6}$ In fact all these concepts may be correct. Low vitamin A may favour tumour incidence by compromising immune reactions which normally can deal with a small number of transformed cells. The presence of tumour cells constitutes a physiological stress, causing an outpouring of adrenocorticotrophic hormone (ACTH), followed by increased glucocortical hormone production by the adrenals. In addition to lympholysis and therefore inhibition of the immune defence against tumour growth, the stress reaction causes a loss of vitamin A. Thus in the presence of a diminished serum and tissue vitamin A content an organism marginally capable of dealing with a carcinogen or a limited number of tumour cells becomes incapable of handling the same challenge. Similarly, inoculation with a higher number of tumour cells may produce, via the stress mechanism outlined above, low serum and tissue levels of vitamin A. ${ }^{7}$ Adrenal and thymus responses to stress may be altered by vitamin A supplementation. ${ }^{8}{ }^{9}$

The very low serum vitamin A levels in patients with oat-cell carcinoma of the lung ${ }^{1}$ may be related to a high serum ACTH level due to ectopic secretion by the tumour cells. This is often encountered in oat-cell carcinomas of the lung and causes markedly augmented cortisol production. ${ }^{10}$ The glucocorticoids so produced antagonise tissue vitamin A by several mechanisms, including that of favouring vitamin A excretion from the body.

A N CRITSELIS

GiUSEPPE RETTURA

E SEIFTER

Department of Surgery and Biochemistry
Albert Einstein College of Medicine, Bronx, New York

${ }^{1}$ Basu, T K, et al, British fournal of Cancer, 1976, 33,

${ }^{2}$ Bjelke, E, International fournal of Cancer, 1975, 15, 561 .

3 Bollag, W, Experientia, 1971, 27, 90. National Cancer Institute, 1973, 50, 439 . National Cancer Institute, 1973, 50, 439.

5enta, V M, et al, Nature, 1974, 247, 48.
6 Rettura, G, et al, fournal of the National Cancer Institute, $1975, \mathbf{5 4}, 1489$.

Institute, 1975, 54, 1489. 172 nd National Meeting, Chicago, 1976, abstract No 67

${ }^{8}$ Cohen, B E, and Cohen, I K, fournal of Immunology, $1973,111,1376$

Seifter, E, et al, American Chemical Society (AGFD), 172nd National Meeting, Chicago, 1976, abstract No 66 .

${ }^{\circ}$ Odell, W D, in Textbook of Endocrinology, ed R H Williams, 5th edn, p 1105. Philadelphia, Saunders,

Phenformin as a cause of primary pulmonary hypertension

SIR,-Your leading article (25 September, p 718) on this subject points to the fact that drugs have been implicated as a cause of pulmonary hypertension. You mention only the anorectic agent aminorex fumarate and oral contraceptives. Even if the number of cases are few it is important to mention every drug with which a likely relationship has been found. It is thus relevant to cite the reports on pulmonary hypertension occurring in patients taking phenformin. ${ }^{1-3}$ In our two cases it was striking that immediate improvement was seen after the withdrawal of phenformin. ${ }^{3}$ In one of the patients the pulmonary hypertension, found by catheterisation and other noninvasive investigations, was to a great extent reversible after withdrawal of the drug. In the other patient the clinical course was progressive and fatal after an initial phase of improvement, and necropsy gave support to the diagnosis. This note may perhaps direct further attention to drugs as a cause of pulmonary hypertension.

MARTIN FAHLÉN

Kungälv Hospital

Kungälv, Sweden

'Sproule, B J, et al, Canadian Medical Association fournal, 1966, 94, 141.

Duwoos, H, et al, Presse Médicale, 1970, 78, 23

Fahlén, M, et al, British Heart fournal, 1973, 35. 824.

\section{Hospital Medical Staffs Defence Trust}

SIR,-The Central Committee for Hospital Medical Services is in the process of discussing with the DHSS the proposed new consultant contracts. Such negotiations are inevitably prolonged in as much as agreements require careful discussion and adequate legal representation. These procedures are naturally costly, hence an appeal from the Hospital Medical Staffs Defence Trust for funds was made about 18 months ago.

In this district we had found it very difficult to get individual consultants to send subscriptions to the HMSDT. It was decided to make a levy locally and this received excellent support, enabling two relatively large sums to be sent to the Trust. Repeated requests for acknowledgement of the receipt of the moneys were made and eventually, after some considerable time, produced the required reply.

Courtesy and politeness, we are taught, cost nothing and this behaviour might make prospective donors to an important and necessary fund somewhat reluctant in the future. We wonder if any other hospital medical staff or consultants have experienced the same problem?

$$
\begin{array}{r}
\text { J R M GibsoN } \\
\text { Honorary Secretary, } \\
\text { Joint Medical Staff Committee, } \\
\text { W Sussex AHA, } \\
\text { Chichester District }
\end{array}
$$

Royal West Sussex Hospital,

***The Secretary writes: "We regret that owing to an oversight as a result of change of staff an earlier contribution from the Joint Medical Staff Committee, Chichester, to the HMSDT was not acknowledged as quickly as we would have liked and we apologise for this. The trustees of the HMSTD are most grateful for all the work which local secretaries like Mr Gibson undertake to raise money for the trust."-ED, $B M \mathcal{H}$.

\section{Fees for HGV licence examinations}

SIR,-Dr T P C Schofield (20 November, $p$ 1262) has drawn attention to the different fees payable for examinations for heavy goods vehicle licences. These have been, with effect from 1 April 1975, £5.50 when paid by local authorities, $£ 6.23$ when paid by Government departments, and $£ 6.55$ when paid by the patient.

The fees payable to doctors for the many services they do outside the NHS are complex -the BMA's fees pamphlet runs to several 